\title{
INDEKS BUDI PEKERTI PRIBADI DALAM KARYA RAJA ALI HAJI
}

\author{
Abdul Malik ${ }^{1}$, Isnaini Leo Shanty ${ }^{2}$ \\ ${ }^{1,2)}$ Program Studi Pendidikan Bahasa dan Sastra Indonesia, \\ Fakultas Keguruan dan Ilmu Pendidikan \\ Universitas Maritim Raja Ali Haji, Tanjungpinang, Kepulauan Riau, Indonesia \\ e-mail: malik@umrah.ac.id
}

\begin{abstract}
This paper is a result of the research of personal character index in the works of Raja Ali Haji. The paper aims to: (1) analyze the character index within selves in the works of Raja Ali Haji, (2) investigate the relationship between personal character index and the teachings of Islam in the works of Raja Ali Haji, and (3) analyze the semiotics class of personal character index in the works of Raja Ali Haji. This study applies semiotics theory of Charles Sanders Peirce. An analysis was performed on five works of Raja Ali Haji, namely Syair Abdul Muluk (The Poem Abdul Muluk), Gurindam Dua Belas (The Twelve Couplets), Thamarat al-Muhimmah (The Desired Fruits), Tuhfat al-Nafis (The Precious Gift), and Syair Sinar Gemala Mestika Alam (The Poem Shining Natural Gem). The data were analyzed using content analysis technique. The research results found that (1) Raja Ali Haji's works contain nineteen personal character indexes, (2) the values of personal character index is interrelated to Islamic teachings, and (3) semiotics class of personal character index in the works of Raja Ali Haji is comprised of rheumatic iconic qualisign, rheumatic indexical sinsign, dicent indexical legisign, and argument. As a result, Raja Ali Haji's works can be referred to as a way of life and is worthy of use as learning materials for character education sourced from the literary works.
\end{abstract}

Key words: index, values, budi, character, character education

\section{PENDAHULUAN}

Raja Ali Haji rahimahullah (1809-1873) adalah penulis yang paling masyhur di antara para intelektual Kerajaan RiauLingga pada abad ke-19. Beliau telah menulis dua buah buku dalam bidang bahasa Melayu yang juga bercampur dengan bidang pendidikan yaitu Bustan alKatibin (1850) dan Kitab Pengetahuan Bahasa (1858). Buah karya beliau yang lain dalam bidang hukum dan pemerintahan yaitu Muqaddima Fi Intizam (1887) dan Tsamarat Al-Muhimmah
(1888). Karya beliau dalam bidang sejarah yaitu Tuhfat Al-Nafis (1865), Silsilah Melayu dan Bugis (1866), Tawarikh alSughra, Tawarikh al-Wusta, Tawarikh alKubra, Peringatan Sejarah Negeri Johor, serta Sejarah Riau-Lingga dan Daerah Takluknya. Beliau pun menulis dalam bidang filsafat Melayu yang bersumber dari agama Islam yang digubah dalam bentuk puisi, karya yang sangat terkenal di Indonesia, Malaysia, dan Dunia Melayu lainnya, yakni Gurindam Dua Belas (1847). Tulisan beliau dalam bidang sastra (syair), yang juga bercampur dengan 
bidang agama yaitu Syair Abdul Muluk (1846), Syair Suluh Pegawai (1866), Syair Siti Shianah (1866), Syair Awai, Syair Sinar Gemala Mestika Alam (1895), Syair Taman Permata, dan Syair Warnasarie. Jenis puisi yang khas, yakni campuran pantun dan syair juga ditulis oleh beliau yaitu Ikat-Ikatan Dua Belas Puji (1858).

Di dalam karya beliau Gurindam Dua Belas, pada Pasal yang Kelima, bait 1, Raja Ali Haji mengatakan, "Jika hendak mengenal orang berbangsa, lihatlah kepada budi dan bahasa." Kenyataan itu menunjukkan bahwa Raja Ali Haji, sebagai cendekiawan, budayawan, sastrawan, sejarawan, dan pakar agama Islam memandang sangat penting keberadaan kehalusan budi dan budi pekerti bagi manusia (Malik, 2012b:559_ 560). Akan tetapi, perihal kehalusan budi dan budi pekerti dalam karya beliau belum mendapat perhatian para peneliti dan sarjana sampai setakat ini. Kajian terhadap karya beliau selama ini lebih banyak terfokus pada bidang agama, linguistik, sejarah, politik pemerintahan, dan sastra.

Pentingnya kajian ini sejalan dengan kebijakan pendidikan di Indonesia. Sejak 2010 Pemerintah Republik Indonesia, melalui Kementerian Pendidikan Nasional, telah menerapkan kembali pendidikan budi pekerti mulai dari jenjang pendidikan dasar sampai dengan pendidikan tinggi. Dengan pendidikan karakter itu, diharapkan dapat diselenggarakan program pendidikan yang menyeluruh dengan memperhatikan kemampuan sosial, watak, budi pekerti, serta kecintaan terhadap budaya dan bahasa Indonesia sehingga instutusi pendidikan dapat mendorong penciptaan hasil didik yang mampu menjawab kebutuhan sumber daya manusia yang berkualitas. Berhubung dengan itu, perlu dipersiapkan bahan pengembangan pendidikan tersebut sesuai dengan Visi Pendidikan Nasional Indonesia (Pusat Kurikulum, 2010:1).

Kebijakan pendidikan nasional itu menekankan bahwa budaya perlu dikembangkan di setiap satuan pendidikan agar peserta didik tak tercabut dari akar budayanya. Oleh karena itu, pendidikan karakter harus dikembangkan bersamaan dengan penamaan pendidikan nilai, pendidikan moral, dan pendidikan watak. Pendidikan ini bertujuan untuk mengembangkan kemampuan peserta didik dalam membuat keputusan baikburuk, memelihara apa yang baik, dan mewujudkan kebaikan dalam kehidupan sehari-hari dengan sepenuh hati (Pusat Kurikulum, 2010:1-2). Untuk menunjang program tersebut, karya Raja Ali Haji 
sangat relevan untuk dikaji, yang pada gilirannya dapat dikembangkan menjadi bahan pembelajaran pendidikan karakter tersebut.

Masalah khusus yang dikaji dalam penelitian ini adalah (1) nilai apa sajakah yang menjadi indeks budi pekerti pribadi dalam karya Raja Ali Haji?, (2) adakah hubungan antara nilai budi pekerti pribadi dan ajaran agama Islam dalam karya Raja Ali Haji?, dan (3) tergolong kelas semiotik apakah nilai budi pekerti pribadi dalam karya Raja Ali Haji? Berhubung dengan itu, ada tiga tujuan khusus penelitian ini: (1) untuk menganalisis nilai yang menjadi indeks budi pekerti pribadi dalam karya Raja Ali Haji, (2) untuk mengkaji hubungan antara nilai budi pekerti pribadi dan ajaran agama Islam dalam karya Raja Ali Haji, dan (3) untuk menganalisis golongan kelas semiotika nilai budi pekerti pribadi dalam karya Raja Ali Haji.

Penelitian ini penting artinya untuk memperkaya bahan pembelajaran pendidikan budi pekerti dan pendidikan sastra. Di samping itu, dari penelitian ini akan dapat dilestarikan, dikembangkan, dan dimanfaatkan warisan budaya takbenda (intangible cultural heritage) sebagai pedoman hidup manusia, terutama generasi muda, untuk membentuk karakternya.

\section{TINJAUAN PUSTAKA}

\section{Konsep Budi dan Budi Pekerti}

Budi merupakan istilah yang berasal dari bahasa Sansekerta, yaitu dari akar kata feminin budh. Oleh karena itu, konsep budi sejalan dengan filsafat Hindu yang menjelaskan bahwa budi memiliki arti yang sangat dalam dan unsur kejiwaannya pun sangat tinggi. Purucker (Ed.) (dalam Ahmat (2000/2001) menjelaskan konsep budi sebagai berikut ini.

"Buddhi (Sanskrit) [from the verbal root "budh" to awaken, enlighten, know] The spiritual soul, the faculty of discriminating, the channel through which streams divine inspiration from the Atman to the ego, and therefore that faculty which enables us to discern between good and evil-spiritual conscience. The qualities of the buddhic principle when awakened are higher judgement, instant understanding, descriminating, intuition, love that has no bounds, and consequent universal forgiveness.

Buddhi uses manas (intellect) as its garment, and in the former are likewise stored the fruitages of many incarnations on earth; hence buddhi is often called both the seed and flower of manas. Buddhi is truly the center of spiritual consciousness and therefore its qualities are enduring." 
Konsep budi dalam agama Hindu, menurut Osborn dan van Loon (1996:6364), adalah sebagai berikut.

"It is argued that the world is formed as purusha (spirit or Atman) infuses prakriti (matter or original nature), and that is stimulates the three states of prakriti. These three states, satya (transparency), rajas (activity), tamas (inactivity). These forces interact and play the different parts in the development of prakriti. As prakriti is activated it becomes Buddhi (intellect), out of which individual egos evolve."

Walaupun konsep budi berasal dari bahasa Sansekerta yang mengandungi filsafat Hindu, dalam budaya Melayu konsep itu mengalami modifikasi. Hal ini karena budaya Melayu berdasarkan ajaran Islam sehingga nilai-nilai Islam-lah yang menjadi rujukan utama konsep budi dalam budaya Melayu-Islam.

Bukhari al-Jauhari menjelaskan perihal budi dalam karyanya Taj al-Salatin (Braginsky, 1994:206-208). Penjelasan itu dapat disarikan menjadi empat belas ciri, antara lain, budi merupakan entitas yang paling dekat dengan Allah, asal segala kebenaran yang ditunjukkan oleh Allah, memancarkan cahaya kebenaran ke seluruh tubuh manusia, keberadaannya menyebabkan dapat dibedakan antara yang baik dan yang buruk, membawa kesempurnaan diri dan perbuatan manusia, dan unsur yang wajib ada dalam diri manusia agar tak mendapat celaka.

$$
\text { Menurut Raja Ali Haji }
$$

(1986/1987:216), budi memuliakan manusia, mencegah manusia berbuat salah, sesuatu yang memungkinkan manusia mendapatkan pengetahuan yang sukarsukar karena budi itu ibarat cahaya yang terang-benderang. Tempat budi itu di dalam hati yang cahayanya terus memancar naik ke dan mengendalikan otak (pikiran) sehingga manusia dapat membedakan yang benar dengan yang salah dan yang baik dengan buruk. Budi itu juga menjelma ke dalam perilaku. Oleh karena itu, seseorang yang memiliki cahaya budi mendapat kemuliaan dari Allah.

Hati tempat bersemayamnya budi itu semakin jelas terlihat dari asal katanya dalam bahasa Arab. Dalam bahasa Arab, menurut Rahman et al., 2010:228, ada beberapa kata yang mengacu kepada makna 'hati' dalam bahasa Indonesia, tetapi dengan kedalaman makna yang berlapis-lapis. Kata-kata itu adalah qalb yaitu dimensi hati yang terluar, lebih dalam lagi ada fuâd yaitu dimensi hati yang merujuk kepada akal yang mengandungi potensi kecerdasan intelektual, ke dalam lagi ada pula 
tsaqâfah yaitu dimensi hati yang memiliki kecerdasan rohani, lebih dalam lagi ada $l u b b$ yang mengandungi semua kecerdasan intelektual dan kecerdasan rohani, dan dimensi hati yang terdalam adalah sirr yang mengandungi rahasia kerohanian yang paling dalam.

Di dalam wasiatnya, Syaiyidina Ali bin Abi Thalib r.a. mengemukakan nasihat tentang pentingnya peran atau fungsi hati. Wasiat beliau sebagai berikut ini (Yazdi, 2012:23-67).

"Maka wahai putraku, aku berwasiat kepadamu untuk bertakwa kepada Allah dan mematuhi perintahperintah-Nya, hidupkan hatimu dengan selalu mengingat-Nya dan berpegang teguhlah pada tali-Nya (ketaatan dan penghambaan). Dan ikatan apa yang dapat lebih dipercaya dan diandalkan dibandingkan dengan ikatan antara engkau dengan Tuhanmu (Allah) Jalla Jalaluhu, asal engkau sungguh-sungguh dalam menjalinnya."

Hati memiliki dua sisi: yang mengarah kepada kebaikan harus dihidupkan dengan nasihat, tetapi yang terikat kepada dunia harus dimatikan dengan kezuhudan (introspeksi diri). Ada sisi hati (keinginan) yang bersifat Ilahiah dan yang bersifat hewani dan syaitaniah, itulah yang mesti dimatikan. Keinginan manusia juga terbagi kepada dua bagian: keinginan yang mengarah kepada Allah dan surga dan keinginan yang mengarah kepada syaitan dan neraka. Hati yang hidup, kuat, dan mengarah kepada Allah serta surgalah yang mesti dipelihara (Yazdi, 2012:37-67).

Perhubungan antara hati dan lapisan-lapisannya yang melahirkan budi dapat digambarkan dengan Bagan 1 yang berikut ini.

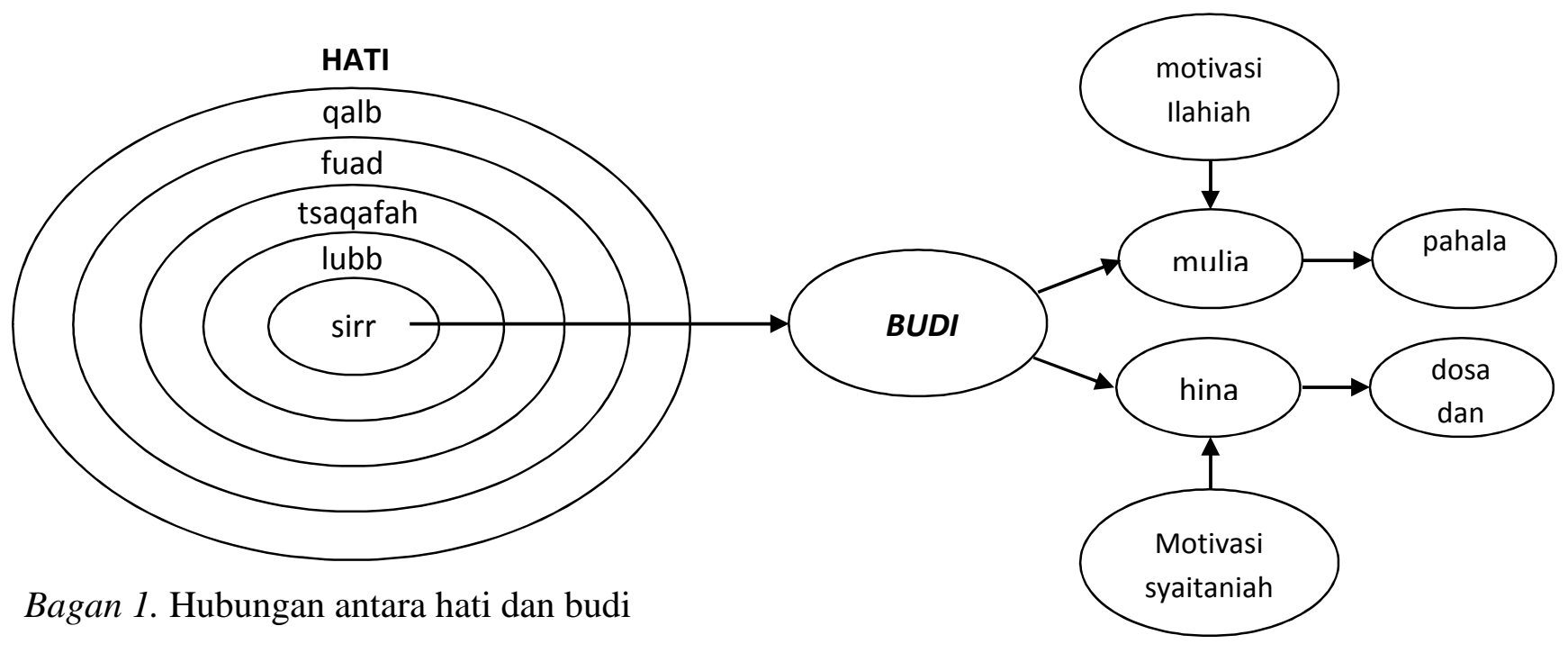


Seperti tergambar dalam Bagan 1 di atas, budi yang baik mendatangkan kemuliaan berasal dari keinginan yang bermotivasi Ilahiah. Dalam pada itu, budi yang buruk mendatangkan kehinaan bersumber dari keinginan yang berasal dari dorongan syaitaniah.

Budi pekerti merupakan ungkapan dalam bahasa Indonesia yang juga berasal dari bahasa Sansekerta. Selanjutnya, kata pekerti berarti 'penampilan, pelaksanaan, aktualisasi, tabiat, dan atau perilaku'. Dengan demikian, secara etimologis budi pekerti berarti 'perilaku atau penampilan diri yang berbudi' (Malik, 2012a:2).

Berdasarkan pendekatan etika atau filsafat moral, budi pekerti adalah watak atau tabiat khusus seseorang untuk berbuat sopan dan menghargai pihak lain yang tercermin dalam perilaku dan kehidupannya. Watak itu merupakan keseluruhan dorongan, sikap, keputusan, kebiasaan, dan nilai moral yang baik pada diri seseorang, yang tercakup dalam satu istilah kebajikan (Zuriah, 2008:18).

Budi pekerti berkaitan dengan akhlak. Istilah akhlak adalah bentuk jamak yang berasal dari kata khuluq dalam bahasa Arab yang bermakna 'adat kebiasaan, perangai, tabiat, watak, adab, agama, sifat asal, marwah, gambaran batin, dan atau budi pekerti' (Alfan, 2011:17; Ahmat, 2000/2001:110; dan Gazalba, 1981:511). Menurut Alfan (2011:21), akhlak dalam bahasa Arab bermaksud sajiyyah 'perangai', mur'uah 'budi', thab'in 'tabiat', dan $a d a b$ 'sopan santun'.

Walaupun akhlak bagian dari etika, keduanya berbeda secara mendasar. Akhlak, berdasarkan ajaran Islam, dibentuk oleh rukun iman dan rukun Islam melalui proses ihsan, ikhlas, dan takwa (Gazalba, 1981:511). Sebaliknya, etika hanya berdasarkan akal-pikiran. Budi pekerti sama maknanya dengan akhlak dan budi yang baik akan melahirkan budi pekerti atau akhlak yang mulia.

\section{Landasan Teoretis}

Untuk menganalisis indeks budi pekerti, penelitian ini menggunakan teori semiotika. Semiotika adalah ilmu tentang sistem tanda (sign). Ilmu ini memiliki tradisi semenjak zaman Greek Stoics (Cobley dan Jansz, 1999:5). Semiotika adalah teori mengenai tanda yang dikomunikasikan. Teori ini lazim digunakan dalam pelbagai disiplin ilmu. Dua tokoh perintis semiotika adalah Ferdinand de Saussure, pakar bahasa Swiss, dan Charles Sanders Peirce, filosof Amerika Serikat (Bakar, 2006:28). 
Peirce menganggap bahwa manusia berpikir dalam tanda (sign). Tanda merupakan suatu unsur dalam komunikasi. Fungsi esensial sebuah tanda adalah membuat relasi yang tak efisien menjadi efisien. Komunikasi, pemikiran, dan pemahaman kita berkenaan dengan apa pun di dunia ini menjadi efisien karena adanya tanda. Singkatnya, fungsi esensial tanda adalah membuat segala sesuatu menjadi efisien.

Berdasarkan ciri-ciri tanda, van Zoest (1993:18) membuat simpulan: segala sesuatu dapat dianggap sebagai tanda. Syaratnya sesuatu itu dapat membuat hubungan segitiga dengan sebuah ground, sebuah denotatum, dan sebuah interpretant.

Menurut Peirce (Pateda, 2001:44; Sobur, 2006:41), tanda "is something wich stands to somebody for something in some respect or capacity." Sesuatu yang digunakan agar tanda dapat berfungsi, oleh Peirce, disebut ground. Konsekuensinya, tanda (sign atau representamen) selalu terdapat dalam hubungan triadik: ground, object, dan interpretant.

Peirce, menurut van Zoest (1993:18-22), membedakan tanda berdasarkan sifat ground-nya atas tiga kelompok: (1) firstness (kepertamaan), (2) secondness (kekeduaan), dan (3) thirdness (keketigaan). Berdasarkan sifat ground, tanda dibedakan atas tiga macam: qualisign, sinsign, dan legisign.

Tanda berhubung pula dengan denotatum. Peirce menyebut denotatum itu objek. Menurut van Zoest (1993:22-23), denotatum adalah kenyataan yang ditunjuk oleh sesuatu tanda. Denotatum merupakan sebuah himpunan atau kelas dari designata. Peirce membagi tiga jenis tanda berdasarkan sifat hubungan antara tanda dan denotatum-nya. Ketiga tanda tersebut adalah icon (ikon), index (indeks), dan symbol (simbol) (van Zoest, 1993:2427).

Ikon adalah tanda yang ada sebagai kemungkinan, tanpa tergantung pada adanya sesebuah denotatum, tetapi dapat dihubungkan dengan denotatum tertentu berdasarkan persamaan potensial yang dimilikinya. Peta, gambar (foto), dan lukisan adalah tanda ikonik karena ada hubungan persamaannya dengan denotatum-nya.

Indeks adalah tanda yang tergantung pada adanya sebuah denotatum. Dalam indeks, perhubungan antara tanda dan denotatum-nya bersebelahan. Segala sesuatu yang memusatkan perhatian pada sesuatu yang lain merupakan indeks: jari 
yang diacungkan, penunjuk arah mata angin, deheman penuh makna, dan katakata deiktis (di sini, hari ini, ini, dan lainlain).

Simbol adalah tanda yang perhubungan antara tanda dan denotatumnya ditentukan oleh peraturan yang berlaku umum. Simbol merupakan tanda yang dihubungkan dengan peraturan umum . Dengan demikian, tanda simbolik adalah tanda melalui perjanjian (van Zoest, 1993:25-27).

Berdasarkan pembedaan tandatanda, dapat dibuat tipologi tanda. Peirce membedakan sepuluh kelas tanda (van Zoest, 1993:31-33). Pertama, qualisign atau lengkapnya qualisign ikonik rhematik, sifat 'kuning, biru, merah, putih' misalnya. Kedua, sinsign ikonik yang selalu merupakan rheme yaitu tanda yang menunjukkan kemiripan seperti gambar (foto), diagram, peta, dan tanda baca. Ketiga, sinsign indeksikal rhematik adalah tanda berdasarkan pengalaman langsung, yang secara langsung menarik perhatian karena kehadirannya disebabkan oleh sesuatu. Keempat, sinsign dicent yang selalu berupa indeksikal yaitu tanda yang memberikan informasi tentang sesuatu. Kelima, legisign ikonik yang selalu merupakan rheme yaitu tanda yang menginformasikan norma atau hukum. Keenam, legisign indeksikal rhematik yaitu tanda yang mengacu kepada objek tertentu, misalnya deiksis 'di sini, kini' terlepas dari konteks atau situasi. Ketujuh, legisign indeksikal dicent yaitu tanda yang bermakna informasi dan menunjuk subjek informasi. Kedelapan, simbol rhematik yang selalu merupakan legisign yaitu tanda yang dihubungkan dengan objeknya melalui asosiasi ide umum. Kesembilan, simbol dicent yang selalu merupakan legisign yaitu tanda yang langsung menghubungkan dengan objek melalui asosiasi dalam otak. Kesepuluh, argument yang selalu merupakan simbol dan legisign yaitu tanda yang merupakan inferensi seseorang terhadap sesuatu berdasarkan alasan tertentu.

Menurut Eco (1979:15), Littlejohn (1996:64), dan Manning (1987:26), dalam semiotika, tanda, objek, dan makna membina hubungan segitiga. Penanda mewakili objek yang menjadi petanda. Penerima menghubungkan tanda dengan objek dan makna sehingga menghasilkan interpretant, yang berfungsi sebagai perantara antara penanda dan petanda. Makna tanda wujud di dalam pikiran penerima setelah dia menghubungkan tanda dengan objek. 
Teks sastra secara keseluruhan adalah tanda dengan semua cirinya. Bagi pembaca, teks sastra menggantikan sesuatu yang lain yakni kenyataan fiksional. Tanda ini timbul karena ditulis oleh pengirimnya, terutama penulisnya. Teks itu merupakan suatu tanda yang dibangun dari tandatanda lain yang lebih rendah, yang memiliki sifat kebahasaan dan sebagainya (van Zoest, 1993:61-63). Tanda-tanda bahasa memang paling banyak di dalam teks sastra, tetapi tanda-tanda nonbahasa juga memainkan peran yang cukup berarti. Sebuah teks dibangun dari banyak tanda lain yang tak terbatas jumlahnya.

Wawasan semiotika dalam kajian sastra memiliki tiga asumsi (Aminuddin, 1997:77). Pertama, karya sastra merupakan gejala komunikasi yang berkaitan dengan (1) pengarang, (2) wujud sastra sebagai sistem lambang, dan (3) pembaca. Kedua, karya sastra merupakan salah satu bentuk penggunaan sistem lambang yang memiliki struktur dalam tingkatan tertentu. Ketiga, karya sastra merupakan fakta yang harus direkonstruksikan pembaca sejalan dengan dunia pengalaman dan pengetahuan yang dimilikinya. Dalam literary semiotics karya sastra disikapi dengan literary discourse. Sasaran kajian sastra secara ilmiah bukan pada maujud konkret wacananya, melainkan pada metadiscourse atau bentuk dan ciri-ciri kewacanaan yang tak teramati secara konkret.

Tanda indeksikal adalah tanda eksistensial yang paling penting. Menurut van Zoest (1993:79-80), tanda-tanda indeksikal dalam sebuah teks dapat dibedakan atas tiga kategori. Pertama, indeks yang menunjuk kepada kebenaran di luar teks seperti semua perkataan yang juga digunakan di luar sastra untuk mengacu kepada benda, isi pikiran, dan sebagainya. Kedua, indeks yang menunjuk kepada teks lain yakni unsur-unsur teks atau struktur yang menempatkan teks dalam tradisi sastra yang lazim. Ketiga, indeks yang menunjuk kepada unsur lain dalam teks (intratekstualitas). Intertekstualitas dan intratekstualitas samasama memberikan koherensi pada suatu teks dan membangun dunia fiktif globalnya.

Sistem komunikasi verbal mengandung komponen: (1) pembicara (addresser), (2) konteks pertuturan, (3) pesan, (4) contact, (5) kode sebagai wahana encoding dan decoding, dan (6) pendengar (addressee). Dalam komunikasi tersebut, pembicara dan pendengar berada dalam hubungan langsung. Dihubungkan 
dengan komponen-komponen komunikasi itu, bahasa sebagai wahana memiliki fungsi berbeda-beda. Setelah dihubungkan dengan karakteristik komunikasi sastra, fungsi bahasa ditentukan meliputi fungsi (1) emotif, (2) referensial, (3) puitik, (4) fatis, (5) metalinguistik, dan (6) konatif (Hymes dalam Stubbs, 1983:46).

Dalam penelitian sastra dengan pendekatan semiotika, tanda yang berupa indeks yang paling banyak dicari yaitu tanda yang menunjukkan hubungan sebabakibat. Penelitian semiotika itu, menurut Preminger et al. (1974), memandang objek-objek atau laku-laku sebagai parole (laku tuturan) dari suatu langue (bahasa: sistem linguistik) yang menjadi dasar tata bahasanya harus dianalisis.

\section{METODOLOGI PENELITIAN}

Dari dua puluh karya Raja Ali Haji, hanya lima karya terpilih yang dianalisis dalam penelitian ini. Kelima karya itu adalah (1) Syair Abdul Muluk, disingkat SAM (1846), (2) Gurindam Dua Belas, disingkat GDB (1846/1847), (3) Tsamarat al-Muhimmah, disingkat TAM (1858), (4) Tuhfat al-Nafis, disingkat TAN (1865), dan (5) Syair Sinar Gemala Mustika Alam, disingkat SGMA (1895).

Ditinjau dari sifat datanya, kajian ini tergolong penelitian deskriptif kualitatif. Penelitian jenis ini merupakan bidang metodologi yang kompleks dan cakupannya luas sekali, yang boleh jadi meliputi beberapa jilid buku (Trochim, 2000:3-8).

Data penelitian ini dikumpulkan dan dianalisis dengan menggunakan teknik analisis isi karena yang dianalisis adalah kandungan isi karya-karya Raja Ali Haji. Konsep yang dikaji adalah indeks budi pekerti yang akan ditemukan setelah dianalisis kandungan isi karya-karya tersebut. Menurut Stephenson (2000:21), analisis isi adalah kajian yang dilakukan untuk menentukan keberadaan kata-kata atau konsep-konsep tertentu dalam teks atau serangkaian teks. Dalam penelitian ini yang dianalisis adalah keberadaan makna dan perhubungan kata-kata dengan konsep-konsep budi pekerti, seterusnya ditarik simpulan yang berkaitan dengan amanat yang terdapat di dalam karyakarya Raja Ali Haji.

\section{HASIL PENELITIAN DAN \\ PEMBAHASAN}

\section{Indeks Budi Pekerti terhadap Diri Sendiri}

Berdasarkan hasil analisis data, ditemukan indeks budi pekerti pribadi dalam karya Raja Ali Haji. Temuan itu diperoleh 
setelah dilakukan analisis data sesuai dengan teori, metode, dan teknik analisis data yang digunakan dalam penelitian ini. Berikut ini hasil penelitian dan pembahasannya.

Karya Raja Ali Haji Gurindam

Dua Belas dimulai dengan Pasal yang Pertama, yang menyajikan bait 1 sebagai berikut ini (Haji, 1946:1).

Barang siapa tiada mengenal agama Sekali-kali tiada boleh dibilangkan nama

Ungkapan barang siapa pada bait gurindam di atas mengacu kepada siapa saja, pribadi-pribadi, atau sesiapa pun. Hal itu berarti seruan atau amanatnya ditujukan kepada semua manusia. Dalam hal ini, setiap manusia seyogianya mengenal agama yang diyakininya.

Ungkapan mengenal agama itu pun tak terbatas pada mengenal saja, tetapi juga meyakini, mempelajari, memahami, dan mengamalkan ajaran agama. Dengan perkataan lain, mengenal agama mencakupi makna yang luas, yakni melaksanakan ajaran atau taat beragama. Hal itu menjadi lebih jelas dalam pasalpasal dan bait-bait berikutnya karena pasal-pasal dan bait-bait Gurindam Dua Belas berkait-kaitan antara satu dan lainnya berhubung dengan masalah akidah, ibadah, muamalah, dan akhlak.

Barang siapa mengenal yang empat Ia itulah orang yang makrifat
Barang siapa mengenal Allah

Suruh dan tegahnya tiada ia menyalah

Barang siapa mengenal diri

Maka telah mengenal Tuhan Yang

Bahari

Barang siapa mengenal dunia

Tahulah ia barang yang terpedaya

Barang siapa mengenal akhirat

Tahulah ia dunia mudarat

Pasal yang Pertama, bait 2 sampai dengan 5 gurindam (Haji, 1946:1) di atas menjelaskan kategori orang yang mengenal agama. Kategori yang dimaksudkan itu adalah mengenal Allah, mengenal diri, mengenal dunia, dan mengenal akhirat. Keempat hal itu harus dikenal karena agama Islam mengajarkan semua hal itu kepada penganutnya. Jelaslah bahwa bait-bait itu mengemukakan persoalan akidah atau keyakinan beragama. Dari keyakinan itulah, kemudian, umat Islam diperintahkan untuk beribadah seperti yang tertera pada Pasal yang Kedua Gurindam Dua Belas (Haji, 1946:2).

Barang siapa mengenal yang tersebut Tahulah ia makna takut

Barang siapa meninggalkan sembahyang

Seperti rumah tiada bertiang

Barang siapa meninggalkan puasa Tidaklah mendapat dua termasa 
Barang siapa meninggalkan zakat

Tiadalah hartanya beroleh berkat

Barang siapa meninggalkan haji

Tiadalah menyempurnakan janji

Pasal yang Kedua Gurindam Dua

Belas ternyata berhubung dengan anjuran untuk melaksanakan ibadah wajib di dalam agama Islam. Kesemuanya itu mengarah kepada perbuatan yang bercirikan ketaatan menjalankan ajaran agama Islam. Jelaslah bahwa menurut karya Raja Ali Haji, ketaatan beragama merupakan indeks budi pekerti. Dengan perkataan lain, seseorang manusia dapat digolongkan kepada insan yang memiliki kehalusan budi pekerti jika dia taat melaksanakan ajaran agamanya. Hal itu disebabkan oleh agamalah, dalam konteks ini agama Islam, yang menganjurkan setiap pemeluknya untuk menjaga kehalusan budi pekerti dan akhlak yang mulia. Jadi, barang siapa yang taat menjalankan perintah agamanya pastilah dia memiliki budi pekerti.

Perihal ketaatan beragama yang menjadi indeks budi pekerti itu dikemukakan juga di dalam karya Tsamarat al-Muhimmah. Berikut ini disajikan petikannya.

"Syahdan inilah segala sebab yang mengesahkan menjadi raja. Adapun segala syaratnya 'allal jumlah. Bahwa hendaklah segala raja itu Islam yang teguh memegang agama Islam ..." (Haji dalam Malik, 2012:29).

Walaupun ditujukan kepada raja, amanatnya meliputi siapa saja atau semua manusia. Pasalnya, setiap orang yang beragama, pemimpin atau bukan, kesemuanya berkewajiban menjalankan ajaran agamanya jika ditinjau dari ajaran agama Islam. Jadi, Tsamarat alMuhimmah pun menegaskan ketaatan beragama menjadi kualitas yang menjadi indeks budi pekerti, yang dipertegas lagi dengan syair bait 7 di dalam karya tersebut.

Hendaklah anakanda mengaji selalu

Dari yang lain lebihkan dulu

Had syara' jangan dilalu

Tidaklah anakanda beroleh malu

Di dalam karyanya Syair Sinar Gemala Mestika Alam (dalam Malik dan Junus (2000:122-133), Raja Ali Haji menegaskan juga tentang kebenaran ajaran agama Islam. Hal itu, antara lain, dikemukakan pada syair bait 87 sebagai berikut ini.

Ugama Islam kekal berdiri

Ilal akhir yaumid dahari

Mansuh sekalian ugama yang bahari

Yahudi Nasrani demikian peri

\section{Bait 87 Syair Sinar Gemala}

Mestika Alam di atas kembali menegaskan bahwa agama Islam-lah yang paling sempurna diturunkan oleh Allah swt. Oleh karena itu, ketaatan menjalankan ajarannya 
memang dituntut kepada setiap manusia, khususnya umat Islam. Jadi, agar agama yang sempurna itu tetap berdiri dengan kokoh, pemeluknya harus taat menjalankan semua ajaran yang dianjurkan, baik yang wajib maupun yang sunat.

\section{Tabel 1}

Indeks Budi Pekerti Pribadi dalam Karya Raja Ali Haji

\begin{tabular}{|c|c|c|c|c|c|c|}
\hline \multirow{3}{*}{$\begin{array}{l}\text { No. } \\
1\end{array}$} & \multirow[b]{2}{*}{ Indeks } & \multicolumn{5}{|c|}{ Karya Raja Ali Haji } \\
\hline & & SAM & GDB & TAN & TAM & SGMA \\
\hline & 2 & 3 & 4 & 5 & 6 & 7 \\
\hline 1. & Taat Beragama & - & $\begin{array}{l}\text { Pasal I; } \\
\text { Pasal II }\end{array}$ & - & $\begin{array}{l}\text { Hlm. } 29 \text {; } \\
\text { bait } 7\end{array}$ & Bait 87 \\
\hline 2. & Lemah-Lembut & Bait 23 & $\begin{array}{l}\text { Pasal VII, } \\
\text { bait } 9\end{array}$ & - & Bait $20-21$ & - \\
\hline 3. & Rajin Belajar & 25,228 & $\begin{array}{l}\text { Pasal V, bait } \\
4 \text {; Pasal IX, } \\
\text { bait } 7\end{array}$ & Hlm. 291 & Bait 6 & - \\
\hline 4. & Sopan-Santun & Bait 33,165 & $\begin{array}{l}\text { Pasal IV, } \\
\text { bait 9; Pasal } \\
\text { V, bait } 1,6\end{array}$ & - & Bait 2 & - \\
\hline 5. & Jujur & Bait 43, 50 & $\begin{array}{l}\text { Pasal IV, } \\
\text { bait } 5 \text { Pasal } \\
\text { VII, bait } 1\end{array}$ & $\begin{array}{l}\text { Hlm. 56- } \\
57\end{array}$ & - & Bait $53-55$ \\
\hline 6. & Tertib & Bait 165 & $\begin{array}{l}\text { Pasal VII, } \\
\text { bait } 6\end{array}$ & - & Bait 36 & - \\
\hline 7. & Mandiri & Bait 201 & - & - & - & - \\
\hline 8. & Menjaga Diri & Bait 471 & $\begin{array}{l}\text { Pasal VIII } \\
\text { bait 1, 2, 3, } \\
4\end{array}$ & - & Bait 63 & - \\
\hline 9. & Ikhlas & $\begin{array}{l}\text { Bait 506- } \\
509,519\end{array}$ & $\begin{array}{l}\text { Pasal VIII, } \\
\text { bait } 5-6\end{array}$ & - & Hlm. 118 & - \\
\hline 10. & Bijaksana & Bait 518 & $\begin{array}{l}\text { Pasal IX, } \\
\text { bait } 6\end{array}$ & - & Bait 22 & - \\
\hline 11. & Rendah Hati & Bait 520 & $\begin{array}{l}\text { Pasal VIII, } \\
\text { bait } 7\end{array}$ & - & Hlm. 118 & Bait 2 \\
\hline 12. & Kritis & Bait 541 & $\begin{array}{l}\text { Pasal IV, } \\
\text { bait 6; Pasal } \\
\text { VII, bait 2; } \\
\text { Pasal VII, } \\
\text { bait 11; } \\
\text { Pasal VIII, } \\
\text { bait 5; Pasal } \\
\text { VIII, bait 6; } \\
\text { Pasal VIII, } \\
\text { bait 7; Pasal } \\
\text { IX, bait 1 }\end{array}$ & - & Bait 61 & - \\
\hline 13. & Tabah & $\begin{array}{l}\text { Bait 837- } \\
861\end{array}$ & - & - & - & - \\
\hline 14. & Akal Sempurna & Bait 995 & - & - & Bait $42-46$ & - \\
\hline 15. & Membela & Bait 967- & Pasal IX, & Hlm. 141 & Bait 16 & - \\
\hline
\end{tabular}

Setelah dianalisis secara keseluruhan, ditemukan indeks budi pekerti terhadap diri sendiri dalam karya Raja Ali Haji. Indeks tersebut dapat dilihat pada Tabel 1 berikut ini. 


\begin{tabular}{|c|c|c|c|c|c|c|}
\hline & Kebenaran & 968 & bait 1 & & & \\
\hline 16. & $\begin{array}{l}\text { Memelihara } \\
\text { Anggota Tubuh }\end{array}$ & - & Pasal III & - & - & - \\
\hline 17. & Menjaga Hati & - & Pasal IV & & Bait $20-32$ & \\
\hline 18. & Rajin Bekerja & - & $\begin{array}{l}\text { Pasal III, } \\
\text { bait } 4 .\end{array}$ & Hlm. 299 & Bait $4-5$ & - \\
\hline 19. & $\begin{array}{l}\text { Bertanggung } \\
\text { Jawab }\end{array}$ & - & $\begin{array}{l}\text { Pasal V, bait } \\
5\end{array}$ & $\begin{array}{l}\text { Hlm. 284- } \\
285\end{array}$ & Bait 37 & - \\
\hline
\end{tabular}

Keterangan:

Hlm. = halaman

- $\quad=$ tak ada indeks yang bersangkutan

Tabel 1 menyajikan sembilan belas indeks budi pekerti pribadi dalam karya Raja Ali Haji. Indeks tersebut meliputi (1) taat beragama, (2) lemah-lembut, (3) rajin belajar,(4) sopan-santun, (5) jujur, (6) tertib, (7) mandiri, (8) menjaga diri, (9) ikhlas, (10) bijaksana, (11) rendah hati, (12) kritis, (13) tabah, (14) akal sempurna, (15) membela kebenaran, (16) memelihara anggota tubuh,(17) menjaga hati, (18) rajin bekerja, dan (19) bertanggung jawab. Jadi, kesembilan nilai yang menjadi indeks itu seyogianya ada dalam diri setiap pribadi yang memiliki budi pekerti.

Dari Tabel 1 juga dapat diketahui bahwa tak semua karya Raja Ali Haji mengandungi indeks tertentu. Dalam hal ini, indeks taat beragama, misalnya, terdapat di dalam Gurindam Dua Belas, Tsamarat al-Muhimmah, dan Syair Sinar Gemala Mestika Alam, tetapi tak terdapat di dalam Syair Abdul Muluk dan Tuhfat alNafis. Walaupun begitu, setiap teks (karya) yang memerikan indeks tertentu, taat beragama misalnya, saling memberi penjelasan tentang indeks tersebut. Dengan demikian, pentingnya indeks yang diperikan itu menjadi lebih dapat dikesan atau dipahami oleh pembaca. Alhasil, amanatnya lebih menyentuh pikiran dan perasaan pembaca.

\section{Hubungan antara Indeks Budi Pekerti dan Ajaran Agama Islam}

Nilai-nilai yang menjadi indeks budi pekerti pribadi dalam karya Raja Ali Haji ditemukan berhubungan dengan ajaran agama Islam. Indeks ketaatan menjalankan ajaran agama yang dikemukakan di atas, antara lain, tersurat di dalam firman Allah berikut ini.

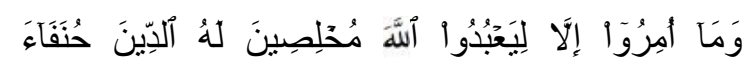

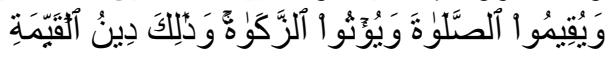
Artinya:

"Padahal, mereka tak disuruh, kecuali supaya menyembah Allah dengan memurnikan ketaatan kepada-Nya dalam (menjalankan) agama yang lurus; dan supaya mereka mendirikan salat dan 
menunaikan zakat; dan yang demikian itulah agama yang lurus," (Q.S. AlBayyinah:5).

Selain firman Allah, pentingnya pemahaman dan ketaatan beragama menurut ajaran Islam ditegaskan juga oleh Rasulullah saw. Penegasan itu, antara lain, terdapat dalam hadits berikut ini.

Dari Anas r.a., Rasulullah saw. bersabda, "Apabila Allah menghendaki kebaikan bagi seseorang hamba, maka Dia membuatnya memahami agama dan membuatnya bersikap zuhud terhadap dunia, lalu Dia memperlihatkan aib-aib dirinya," (H.R. Baihaqi).

Dari firman Allah dan sabda Rasulullah saw. di atas, ternyata memang ketaatan beragama menjadi mutlak bagi setiap manusia. Ketaatan beragama menjadi indeks budi pekerti setiap insan, yang menunjukkan kebaikan diri manusia. Oleh karena itu, melalui karya-karyanya Raja Ali Haji mengungkapkan perihal ketaatan beragama itu agar menjadi pelajaran bagi sesiapa saja yang mengaku beriman dan beragama Islam. Dalam hal ini, ketaatan beragama itulah indeks utama kehalusan budi pekerti, yang memang sesuai dengan firman Allah dan sabda Nabi Muhammad saw. Alhasil, indeks budi pekerti terhadap diri sendiri dalam karya Raja Ali Haji sejalan dengan ajaran agama Islam. Jadi, kebenaran dan kebaikannya tak diragukan ditinjau dari ajaran Islam.

Secara lengkap, temuan penelitian ini tentang hubungan antara indeks budi pekerti pribadi dan ajaran agama Islam dalam karya Raja Ali Haji disajikan pada Tabel 2 berikut ini.

Tabel 2

Hubungan antara Indeks Budi dan Ajaran Agama Islam

\begin{tabular}{|c|c|c|c|}
\hline \multirow{3}{*}{$\begin{array}{c}\text { No. } \\
1\end{array}$} & \multirow{3}{*}{$\begin{array}{c}\text { Indeks } \\
2\end{array}$} & \multicolumn{2}{|c|}{ Ajaran Agama Islam } \\
\hline & & Al-Quran & Al-Hadits \\
\hline & & 3 & 4 \\
\hline 1. & $\begin{array}{l}\text { Taat } \\
\text { Beragama }\end{array}$ & $\begin{array}{l}\text { Surah Al- } \\
\text { Bayyinah:5 }\end{array}$ & $\begin{array}{l}\text { H.R. } \\
\text { Baihaqi } \\
\text { dari Anas } \\
\text { r.a. }\end{array}$ \\
\hline 2. & $\begin{array}{l}\text { Lemah- } \\
\text { Lembut }\end{array}$ & $\begin{array}{l}\text { Surah Ali } \\
\text { 'Imran:159 }\end{array}$ & $\begin{array}{l}\text { H.R. Ibnu } \\
\text { Abid } \\
\text { Dunya }\end{array}$ \\
\hline 3. & $\begin{array}{l}\text { Rajin } \\
\text { Belajar }\end{array}$ & $\begin{array}{l}\text { Surah Al- } \\
\text { Mujaadilah:11 }\end{array}$ & $\begin{array}{l}\text { H.R. Ibnu } \\
\text { Majah dari } \\
\text { Anas bin } \\
\text { Malik }\end{array}$ \\
\hline 4. & $\begin{array}{l}\text { Sopan- } \\
\text { Santun }\end{array}$ & $\begin{array}{l}\text { Surah } \\
\text { Al- } \\
\text { Qasha } \\
\text { sh:55 }\end{array}$ & $\begin{array}{l}\text { H.R. } \\
\text { Syaikhan }\end{array}$ \\
\hline 5. & Jujur & $\begin{array}{l}\text { Surah Al- } \\
\text { Hajj:30 }\end{array}$ & $\begin{array}{l}\text { H.R. } \\
\text { Muslim dan } \\
\text { Turmudzi }\end{array}$ \\
\hline 6. & Tertib & $\begin{array}{l}\text { Surah Al- } \\
\text { Hijr:3 }\end{array}$ & $\begin{array}{l}\text { H.R. } \\
\text { Tirmidzi } \\
\text { dari Abu } \\
\text { Hurairah } \\
\text { r.a. }\end{array}$ \\
\hline 7. & Mandiri & $\begin{array}{l}\text { Surah Al- } \\
\text { Isra':7 }\end{array}$ & $\begin{array}{l}\text { H.R. } \\
\text { Bukhari } \\
\text { dari Abu } \\
\text { Hurairah } \\
\text { r.a. }\end{array}$ \\
\hline 8. & $\begin{array}{l}\text { Menjaga } \\
\text { Diri }\end{array}$ & $\begin{array}{l}\text { Surah Al- } \\
\text { Furqaan:72 }\end{array}$ & $\begin{array}{l}\text { H.R. } \\
\text { Muslim }\end{array}$ \\
\hline 9. & Ikhlas & $\begin{array}{l}\text { Surah Al- } \\
\text { Baqarah:139 }\end{array}$ & $\begin{array}{l}\text { H.R. Nasa'i } \\
\text { dari Abu }\end{array}$ \\
\hline
\end{tabular}




\begin{tabular}{|c|c|c|c|}
\hline & & & $\begin{array}{l}\text { Umamah } \\
\text { al-Bahily } \\
\text { r.a. }\end{array}$ \\
\hline 10. & Bijaksana & $\begin{array}{l}\text { Surah Al- } \\
\text { Baqarah:269 }\end{array}$ & $\begin{array}{l}\text { H.R. } \\
\text { Dailami }\end{array}$ \\
\hline 11. & $\begin{array}{l}\text { Rendah } \\
\text { Hati }\end{array}$ & $\begin{array}{l}\text { Surah Al- } \\
\text { Furqaan:63 }\end{array}$ & $\begin{array}{l}\text { H.R. } \\
\text { Muslim } \\
\text { dari Iyyadh } \\
\text { bin Khimar }\end{array}$ \\
\hline 12. & Kritis & $\begin{array}{l}\text { Surah Asy- } \\
\text { Syams:8-10 }\end{array}$ & $\begin{array}{l}\text { H.R. } \\
\text { Muslim } \\
\text { dari Ibnu } \\
\text { Umar r.a. }\end{array}$ \\
\hline 13. & Tabah & $\begin{array}{l}\text { Surah } \\
\text { Yusuf:87 }\end{array}$ & $\begin{array}{l}\text { H.R. } \\
\text { Bukhari } \\
\text { dari } \\
\text { Abdullah } \\
\text { bin Mas'ud }\end{array}$ \\
\hline 14. & $\begin{array}{l}\text { Akal } \\
\text { Sempurna }\end{array}$ & $\begin{array}{l}\text { Surah } \\
\text { Yunus:100 }\end{array}$ & $\begin{array}{l}\text { H.R. Ibnul } \\
\text { Mahbar } \\
\text { dari Abu } \\
\text { Qatadah } \\
\text { r.a. }\end{array}$ \\
\hline 15. & $\begin{array}{l}\text { Membela } \\
\text { Kebenaran }\end{array}$ & $\begin{array}{l}\text { Surah Al- } \\
\text { Maidah:54 }\end{array}$ & $\begin{array}{l}\text { H.R. } \\
\text { Muslim }\end{array}$ \\
\hline 16. & $\begin{array}{l}\text { Memelihar } \\
\text { a Anggota } \\
\text { Tubuh }\end{array}$ & $\begin{array}{l}\text { Surah Al- } \\
\text { Isra':36 }\end{array}$ & $\begin{array}{l}\text { H.R. } \\
\text { Tirmidzi } \\
\text { dari Abu } \\
\text { Hurairah } \\
\text { r.a. }\end{array}$ \\
\hline 17. & $\begin{array}{l}\text { Menjaga } \\
\text { Hati }\end{array}$ & $\begin{array}{l}\text { Surah Al- } \\
\text { Baqarah:8- } \\
10\end{array}$ & $\begin{array}{l}\text { H.R. } \\
\text { Bukhari } \\
\text { dan Muslim }\end{array}$ \\
\hline 18. & $\begin{array}{l}\text { Rajin } \\
\text { Bekerja }\end{array}$ & $\begin{array}{l}\text { Surah At- } \\
\text { Taubah: } 105\end{array}$ & $\begin{array}{l}\text { H.R. Ath- } \\
\text { Thabrani }\end{array}$ \\
\hline 19. & $\begin{array}{l}\text { Bertanggu } \\
\text { ng Jawab }\end{array}$ & $\begin{array}{l}\text { Surah An- } \\
\text { Nahl:93 }\end{array}$ & $\begin{array}{l}\text { H.R. } \\
\text { Bukhari, } \\
\text { Muslim, } \\
\text { dan } \\
\text { Turmudzi } \\
\text { dari } \\
\text { Abdullah } \\
\text { bin Umar } \\
\text { r.a. }\end{array}$ \\
\hline
\end{tabular}

Keterangan:

H.R. = Hadits yang diriwayatkan oleh

Tabel 2 memperlihatkan hubungan antara kesembilan belas indeks budi pekerti pribadi dan ajaran agama Islam. Ternyata, semua indeks itu berhubungan dengan firman Allah di dalam Al-Quran dan sabda Rasulullah di dalam Al-Hadits. Kenyataan itu menguatkan argumentasi bahwa nilai-nilai budi pekerti yang diperikan oleh Raja Ali Haji di dalam karya-karyanya memang bersumber dari ajaran agama Islam. Dengan demikian, bagi umat Islam, kebenaran dan kebaikan budi pekerti yang dikemukakan oleh Raja Ali Haji itu tak mungkin ditolak.

\section{Kelas Tanda Semiotik Indeks Budi Pekerti}

Bagian ini memerikan golongan kelas tanda semiotik indeks budi pekerti pribadi dalam karya Raja Ali Haji. Temuan penelitian ini menunjukkan bahwa tak semua dari sepuluh kelas tanda yang dikemukakan oleh Peirce (van Zoest, 1993:31-33) terdapat di dalam karya Raja Ali Haji dalam kaitannya dengan indeks budi pekerti terhadap diri sendiri. Dalam hal ini, pemerian tentang indeks budi pekerti itu hanya menggunakan empat kelas tanda semiotik saja.

Ketaatan beragama sebagai indeks budi pekerti pribadi ditampilkan oleh Raja Ali Haji dengan menggunakan argument. Dua pasal Gurindam Dua Belas dan baitbait syair dalam Tsamarat al-Muhimmah dan Syair Sinar Gemala Mestika Alam digunakan untuk menampilkan nilai tersebut (lihat Tabel 1). Sebagai argument, 
tanda yang terdapat dalam karya-karya itu merupakan simpulan Raja Ali Haji tentang orang yang taat beragama berdasarkan alasan tertentu. Dalam hal ini, alasan kebenarannya adalah ajaran agama Islam seperti yang terdapat, antara lain, di dalam Al-Quran, Surah Al-Bayyinah, ayat 5, dan hadits Rasulullah s.a.w. yang diriwayatkan oleh Baihaqi (lihat Tabel 2) bahwa kebaikan seseorang hamba Allah terlihat jika dia memahami dan melaksanakan ajaran agamanya. Alasan itu mengandungi kebenaran menurut keyakinan umat Islam karena berdasarkan petunjuk Allah swt. dan pedoman dari Rasulullah saw.

Selain argument, ketaatan beragama merupakan indeks budi pekerti terhadap diri sendiri dalam karya Raja Ali Haji juga menggunakan qualisign ikonik rhematik. Dalam hal ini, sifat taat dalam beragama itu seyogianya memang sedia ada atau melekat dalam diri setiap orang yang memiliki budi pekerti seperti yang dikemukakan di dalam Gurindam Dua Belas, Tsamarat al-Muhimmah, dan Syair Sinar Gemala Mestika Alam.

Taat beragama sebagai indeks budi pekerti pribadi juga dikemukakan dengan menggunakan tanda semiotik yang tergolong legisign indeksikal dicent. Dalam hal ini, Raja Ali Haji mengungkapkan persoalan itu berdasarkan norma atau peraturan diyakininya, yaitu ajaran agama Islam seperti yang terdapat di dalam firman Allah dan hadits Rasulullah.

Berdasarkan uraian di atas, indeks budi pekerti taat beragama dikemukakan oleh Raja Ali Haji dengan menggunakan tanda semiotik yang tergolong ke dalam tiga kelas, yaitu argument, qualisign ikonik rhematik, dan legisign indeksikal dicent. Secara lengkap, kelas tanda semiotik yang terdapat dalam karya Raja Ali Haji yang berkaitan dengan indeks budi pekerti terhadap diri sendiri dapat dilihat pada Tabel 3 berikut ini.

Tabel 3

Hubungan antara Indeks Budi Pekerti Pribadi dan Kelas Semiotik Pierce

\begin{tabular}{|c|c|c|c|c|c|}
\hline \multirow[b]{2}{*}{ No. } & \multirow[b]{2}{*}{ Indeks } & \multicolumn{4}{|c|}{ Kelas Semiotik } \\
\hline & & $\begin{array}{l}\text { Kelas } \\
\text { I }\end{array}$ & $\begin{array}{c}\text { Kelas } \\
\text { II }\end{array}$ & $\begin{array}{c}\text { Kelas } \\
\text { III }\end{array}$ & $\begin{array}{l}\text { Kelas } \\
\text { IV }\end{array}$ \\
\hline 1 & 2 & 3 & 4 & 5 & 6 \\
\hline 1. & $\begin{array}{l}\text { Taat } \\
\text { Beragama }\end{array}$ & $\sqrt{ }$ & - & $\sqrt{ }$ & $\sqrt{ }$ \\
\hline 2. & $\begin{array}{l}\text { Lemah- } \\
\text { Lembut }\end{array}$ & $\sqrt{ }$ & $\sqrt{ }$ & $\sqrt{ }$ & $\sqrt{ }$ \\
\hline 3. & $\begin{array}{l}\text { Rajin } \\
\text { Belajar }\end{array}$ & $\sqrt{ }$ & $\sqrt{ }$ & $\sqrt{ }$ & $\sqrt{ }$ \\
\hline 4. & $\begin{array}{l}\text { Sopan- } \\
\text { Santun }\end{array}$ & $\sqrt{ }$ & $\sqrt{ }$ & $\sqrt{ }$ & $\sqrt{ }$ \\
\hline 5. & Jujur & $\sqrt{ }$ & $\sqrt{ }$ & $\sqrt{ }$ & $\sqrt{ }$ \\
\hline 6. & Tertib & $\sqrt{ }$ & $\sqrt{ }$ & $\sqrt{ }$ & $\sqrt{ }$ \\
\hline 7. & Mandiri & $\sqrt{ }$ & $\sqrt{ }$ & $\sqrt{ }$ & - \\
\hline 8. & $\begin{array}{l}\text { Menjaga } \\
\text { Diri }\end{array}$ & $\sqrt{ }$ & $\sqrt{ }$ & $\sqrt{ }$ & $\sqrt{ }$ \\
\hline 9. & Ikhlas & $\sqrt{ }$ & $\sqrt{ }$ & $\sqrt{ }$ & $\sqrt{ }$ \\
\hline 10. & Bijaksana & $\sqrt{ }$ & $\sqrt{ }$ & $\sqrt{ }$ & $\sqrt{ }$ \\
\hline 11. & Rendah Hati & $\sqrt{ }$ & $\sqrt{ }$ & $\sqrt{ }$ & $\sqrt{ }$ \\
\hline 12. & Kritis & $\sqrt{ }$ & $\sqrt{ }$ & $\sqrt{ }$ & $\sqrt{ }$ \\
\hline 13. & Tabah & $\sqrt{ }$ & $\sqrt{ }$ & $\sqrt{ }$ & $\sqrt{ }$ \\
\hline & & & & 17 & \\
\hline
\end{tabular}




\begin{tabular}{llll}
\hline 14. $\begin{array}{l}\text { Akal } \\
\text { Sempurna } \\
\text { 15. }\end{array}$ & $\sqrt{ }$ & $\sqrt{ }$ & $\sqrt{ }$ \\
Membela \\
Kebenaran
\end{tabular}
16.

Tabel 3 menyajikan bahwa umumnya indeks budi pekerti terhadap diri sendiri yang terdapat dalam karya Raja Ali Haji menggunakan empat kelas tanda semiotik: qualisign ikonik rhematik, sinsign indeksikal rhematik, legisign indeksikal dicent, dan argument. Hanya indeks taat beragama yang menggunakan tiga kelas tanda, yaitu tanpa sinsign indeksikal rhematik. Hal itu berarti untuk mengemukakan indeks taat beragama Raja Ali Haji tak menampilkan perkataan, perbuatan, dan atau perilaku orang yang taat beragama tersebut. Dalam hal ini, yang ditampilkan hanya pernyataan Raja Ali Haji sendiri sebagai penulis berdasarkan norma yang beliau yakini.
Indeks memelihara anggota tubuh dan menjaga hati pula hanya menggunakan dua kelas tanda semiotik, yaitu legisign indeksikal dicent dan argument. Hal itu berarti hanya pernyataan penulis yang didasari oleh keyakinannya saja yang ditampilkan, sedang pikiran, perasaan, $\sqrt{ }$ sifat, sikap, perkataan, dan atau perilaku orang yang memiliki indeks tersebut tak ditampilkan (tanpa tokoh). Memang itulah yang ditampilkan di dalam Gurindam Dua Belas, Pasal yang Ketiga (memelihara anggota tubuh) dan Gurindam Dua Belas, Pasal yang Keempat dan Tsamarat alMuhimmah, bait 20-32 (menjaga hati).

Kecuali ketiga indeks budi pekerti di atas, semua indeks yang lain menggunakan empat kelas tanda semiotik: qualisign ikonik rhematik, sinsign indeksikal rhematik, legisign indeksikal dicent, dan argument. Hal itu berarti bahwa pemeriannya melibatkan pikiran, perasaan, sifat, sikap, perkataan, dan atau perilaku orang yang memiliki nilai budi pekerti tersebut, pernyataan penulisnya (Raja Ali Haji), dan dilengkapi dengan norma atau peraturan yang mendasari keyakinannya secara tersirat, yakni ajaran agama Islam. 


\section{SIMPULAN DAN SARAN}

\section{Simpulan}

Temuan penelitian ini menunjukkan bahwa karya Raja Ali Haji mengandungi sembilan belas indeks budi pekerti pribadi. Semua indeks budi pekerti itu berhubung dengan ajaran agama Islam. Secara semiotis, indeks budi pekerti itu terdiri atas empat kelas. Pertama, qualisign ikonik rhematik yaitu kualitas pikiran, perasaan, sifat, dan sikap yang sedia ada atau melekat pada orang yang memiliki kehalusan budi pekerti. Kedua, sinsign indeksikal rhematik yaitu kualitas perkataan dan atau tingkah laku seseorang yang dapat didengar dan atau diamati oleh orang lain. Ketiga, legisign indeksikal dicent yaitu tanda yang bermakna informasi dan merujuk kepada subjek informasi berdasarkan norma atau ajaran agama Islam. Keempat, argument yaitu simpulan yang dikemukakan oleh Raja Ali Haji berdasarkan kebenaran yang beliau yakini, yakni bersumber dari norma ajaran agama Islam. Dengan demikian, manusia yang memiliki sembilan belas nilai budi pekerti itu di dalam dirinya tergolong orang yang berbudi pekerti baik.

\section{Saran}

Karya Raja Ali Haji terbukti mengandungi nilai-nilai kehalusan budi pekerti yang memang dijunjung tinggi di dalam budaya bangsa Indonesia dan Dunia Melayu umumnya. Hal itu berarti bahwa karya Raja Ali Haji dapat dan sebaiknya dijadikan bahan pembelajaran pendidikan karakter dan pendidikan sastra untuk memartabatkan kembali jati diri dan peradaban bangsa Indonesia. Bahkan, karena nilainya bersifat universal, nilainilai budi pekerti yang dikemukakan oleh Raja Ali Haji itu juga dapat dijadikan rujukan oleh semua manusia di dunia ini untuk menjadi pedoman hidup.

\section{DAFTAR PUSTAKA}

Ahmad, R. dan Haji, R.A. (1982). Tuhfat alnafis. Dalam Virginia Matheson (Ed.). Petaling Jaya, Malaysia: Penerbit Fajar Bakti Sdn. Bhd.

Ahmat, Z. (2000/2001). Falsafah etika masyarakat Melayu tradisional: Satu kajian berdasarkan pantun Melayu. Disertasi Ijazah Sarjana Sastera, Jabatan Pengajian Media, Fakulti Sastera dan Sains Sosial, Universiti Malaya, Kuala Lumpur, Malaysia.

Alfan, M. (2011). Filsafat etika Islam. Bandung, Indonesia: Pustaka Setia.

al-Jauhari, B. (1994). Taj al-salatin. Dalam V.I. Braginsky. Erti keindahan dan keindahan erti dalam kesusastraan Melayu klasik. Kuala Lumpur, Malaysia: Dewan Bahasa dan Pustaka.

Aminuddin. (1997). Stilistika: Pengantar memahami bahasa dalam karya sastra. Semarang, Indonesia: IKIP Semarang Press. 
Bakar, A.L.A. (2006). Aplikasi teori semiotika dalam seni pertunjukan. Jurnal Etnomusikologi, 2(1), 4551.

Braginsky, V.I. (1994). Erti keindahan dan keindahan erti dalam kesusastraan Melayu klasik. Kuala Lumpur, Malaysia: Dewan Bahasa dan Pustaka.

Cobley, P. dan Jansz, L. (1999). Introducing semiotics. New York, NY: Icon BooksTotem Books.

Eco, U. (1976). A theory of semiotics. Bloomington, USA: Indiana University Press.

Gazalba, S. (1981). Sistematika filsafat: Buku iv. Jakarta, Indonesia: NV Bulan Bintang.

Haji, R.A. (1846). Gurindam dua belas. Batavia, Indonesia.

Haji, R.A. (1986/1987). Kitab pengetahuan bahasa: Kamus logat Melayu Johor, Pahang, Riau, dan Lingga. Dalam Yunus, R.H. (Ed.). Pekanbaru, Riau, Indonesia: Bagian Proyek Penelitian dan Pengkajian Kebudayaan Melayu, Penelitian dan Pengkajian Kebudayaan Nusantara, Departemen Pendidikan dan Kebudayaan.

Haji, R.A. (1988/1989). Syair Abdul Muluk. Dalam Syamsiar, S. (Ed.). Pekanbaru, Riau, Indonesia: Bagian Proyek Penelitian dan Pengkajian Kebudayaan Melayu, Penelitian dan Pengkajian Kebudayaan Nusantara, Departemen Pendidikan dan Kebudayaan.

Haji, R.A. (2012). Tsamarat almuhimmah. Dalam Malik, A. (Ed.). Depok, Indonesia: Komodo Books.
Littlejohn, S.W. (1996). Theories of human communication. New York, NY: Wadsworth Publishing Company.

Mahdini. (1999). Tsamarat al-muhimmah: Pemikiran Raja Ali Haji tentang peradilan. Pekanbaru, Riau, Indonesia: Yayasan Pusaka Riau.

Malik, A. (2012a, April 30). Nilai-nilai budi pekerti di dalam karya-karya Raja Ali Haji. Kertas kerja Seminar Lembaga Adat Melayu Provinsi Kepulauan Riau, Tanjungpinang, Kepulauan Riau, Indonesia.

Malik, A. (2012b). Menjemput tuah menjunjung marwah. Depok, Indonesia: Komodo Books.

Malik, A. dan Junus, H. (2000). Studi tentang himpunan karya Raja Ali Haji. Pekanbaru, Riau, Indonesia: Badan Perencanaan Pembangunan Daerah, Propinsi Riau dan Pusat Penelitian Kebudayaan dan Kemasyarakatan, Universitas Riau.

Matheson, V. (Ed.). (1982). Tuhfat alNafis. Petaling Jaya, Malaysia: Penerbit Fajar Bakti Sdn. Bhd.

Osborn, R. dan van Loon, B. (1996). Ancient eastern philosophy for beginners. Cambridge: Icon Book Ltd.

Pateda, M. (2001). Semantik leksikal. Jakarta, Indonesia: Rineka Cipta.

Peirce, C.S. (1982). Logic as semiotics: The theory of signs. Dalam Innis, R.E. (Ed.), Semiotics: An introductory anthology. Bloomington, USA: Indiana University Press.

Preminger, A. (Ed.). (1974). Princeton encyclopedia of poetry and poetics. 
London, England: The Maxmillan Press Ltd.

Pusat Kurikulum. (2010). Pengembangan pendidikan budaya dan karakter bangsa: Pedoman sekolah. Jakarta, Indonesia: Badan Penelitian dan Pengembangan, Kementerian Pendidikan Nasional.

Rahman, J.D. (Ed.). (2010). Dermaga sastra Indonesia: Kepengarangan Tanjungpinang dari Raja Ali Haji hingga Suryatati A. Manan. Depok, Indonesia: Komodo Books.

Saussure, F.de. (1988). Pengantar linguistik umum. (Terjemahan Rahayu S. Hidayat). Yogyakarta, Indonesia: Gadjah Mada University Press.

Sobur, A. 2006. Semiotika komunikasi. Bandung, Indonesia: Remaja Rosdakarya.

Stephenson, M.S. (2000). Analisis isi. (Terjemahan Diah, M.). Pekanbaru, Riau, Indonesia: Balai Bahasa Pekanbaru, Pusat Bahasa, Departemen Pendidikan Nasional.

Trochim, W.K. (2000). Penelitian kualitatif. (Terjemahan Diah, M.). Pekanbaru, Riau, Indonesia: Balai Bahasa Pekanbaru, Pusat Bahasa, Departemen Pendidikan Nasional.

Ulmann, S. (2007). Pengantar semantik. (Terjemahan Sumarsono). Yogyakarta, Indonesia: Pustaka Pelajar.

van Zoest, A. (1993). Semiotika: Tentang tanda, cara kerjanya, dan apa yang kita lakukan dengannya. (Terjemahan Soekowati, A.). Jakarta, Indonesia: Yayasan Sumber Agung.
Yazdi, M.T.M. (2012). 22 nasihat abadi penghalus budi. Jakarta, Indonesia: Citra.

Zuriah, N. (2008). Pendidikan moral dan budi pekerti dalam perspektif perubahan. Jakarta, Indonesia: Bumi Aksara. 